\title{
Changes in weight and body fat after use of tetracycline and Lactobacillus gasseri in rats
}

\author{
Jorge José Marciano, Fernando de Sá Del Fiol*, Alessandra Cristina Marciano Tardelli Ferreira, \\ Maria Cláudia Marques, Luciane Lopes Santana
}

Pharmacology Department, University of Sorocaba, Sorocaba, SP, Brazil

\begin{abstract}
Recent studies have shown a role of intestinal microbiota in obesity. The consumption of antibiotics in the last 70 years has led to changes in intestinal microbiota, which has led to weight gain and body fat accumulation. To evaluate the possibility of weight gain induced by antibiotics and the possible protective effect of probiotics, we divided 45 animals (Rattus norvegicus) into groups and administered the following treatments over two weeks: tetracycline, tetracycline + Lactobacillus gasseri, and $\mathrm{NaCl}$. The animals were weighed over the course of 8 weeks, and at the end of the treatment period, they were measured and subjected to bioelectrical impedance analysis. The results show that the group receiving tetracycline alone had a higher body mass index $(p=0.030)$, a greater Lee index $(p=0.008)$, and a lower body water percentage than the control group, indicating a greater accumulation of body fat. The group receiving the probiotics with tetracycline presented similar results to the control group, indicating a possible protective effect of body fat accumulation in the group receiving tetracycline alone. The results show that tetracycline increased the concentration of body fat, and the use of probiotics was associated with an ability to protect the animals from the pro-obesity effect.
\end{abstract}

Uniterms: Antimicrobials/evaluation. Obesity/tests. Gut microbiota/tests. Tetracyclines.

\section{INTRODUCTION}

Obesity is currently one of the greatest global public health challenges, and the number of obese people has risen dramatically, especially in Western countries (Riley et al., 2013). In the United States alone, the number of overweight people has doubled from an average of $15.1 \%$ of the population in 1976-1980 to $31.2 \%$ in 2001-2004 (Christian, Rashad, 2009). Obesity is associated with other grave medical conditions, such as cancer, diabetes, hypertension, and cardiovascular disease. Diet and physical inactivity are certainly important causes of obesity, but they are not the only ones. The multifactorial etiology of obesity (Newnham et al., 2009; Riley et al., 2013) also includes changes in the human microbiota (Musso, Gambino, Cassader, 2011; Moreira et al., 2012; Cho et al., 2012; Million et al., 2013; Riley et al., 2013; Martinez, 2014).

\footnotetext{
*Correspondence: F. S. Del Fiol. Universidade de Sorocaba. Rodovia Raposo Tavares, Km 92,5 - 18023-000 - Sorocaba - SP, Brasil. Telefone: 5515996170589 - Fax: 5515 21017074. E-mail: fernando.fiol@prof.uniso.br
}

The human gut microbiota has about 100 trillion bacterial cells that predominantly belong to four bacterial phyla: Proteobacteria, Actinobacteria, Firmicutes, and Bacteroidetes. The latter two represent about $90 \%$ of the organisms found in the gut microbiota (Tilg, Kaser, 2011; Riley et al., 2013). There are 10 times more intestinal bacterial cells than the cells that comprise a human adult. This large number of microorganisms is associated with numerous functions that are developed and mediated by gut microbiota and have led some authors to refer to the gut microbiota as another human organ (Quigley, 2013; Riley et al., 2013; Lankelma et al., 2014; Putignani et al., 2014).

Although relatively stable, the gut microbiota is affected by age, gender, geography, diet, and environmental factors, such as exposure to antibiotics, especially in children and newborns (Backhed et al., 2005; Agans et al., 2011; Vael et al., 2011; Grzeskowiak et al., 2012; Markle et al., 2013; Trasande et al., 2013). There are numerous studies related to gut microbiota changes (dysbiosis) caused by antibiotics and probiotics, including weight modifications in humans and animals (Ley et al., 2006; Turnbaugh et al., 2008; Xu et al., 2012; Bibiloni, Pons, 
Tur, 2013). The relationship between Bacteroidetes and Firmicutes seems to be a major factor in the increase or decrease of energy gain, although there is no consensus on the role of each microorganism in the development of obesity or weight loss (Collado et al., 2008; Li et al., 2008; Turnbaugh et al., 2009; Schwiertz et al., 2010).

In the last 70 years, we have been exposed to large amounts of antibiotics as therapies against infections (Van Boeckel et al., 2014), in antibiotic-contaminated food (Anderson et al., 2003)2003, or in the large amounts dumped into the environment (Sarmah Meyer, Boxall, 2006). This increased exposure, especially in children, may be responsible for the recent obesity epidemic. Studies show that increases in body weight caused by microbial antibiotics is becoming more frequent, particularly when the antibiotic has a broad spectrum of activity. Alternatively, the use of probiotics has been associated with weight loss and could presumably protect against the effect caused by antibiotics in the microbiota (Haight, Pierce, 1955; Saiman et al., 2010; Thuny et al., 2010; Saiman et al., 2012; Trasande et al., 2013).

In a recent meta-analysis involving 88 studies on the effect of Lactobacillus species on the weight of animals and humans, Million et al. (2012) showed that some species were associated with weight gain (L. acidophilus, L. ingluviei, and L. fermentum), while others were associated with weigh loss (L. plantarum and L. gasseri). To discover more information about this phenomenon and to search for possible treatments with a combination of probiotics, this study evaluated the influence of tetracycline with or without a probiotic on the weight and body composition of rats.

\section{METHODS}

Animal care: We used 45 male rats (Rattus norvegicus Wistar) that were 15 days old. The animals were housed in the animal house at the University of Sorocaba, where they stayed for a 10-day adaptation period before the experimental phase. They were fed with standard rodent chow (Presence ${ }^{\circledR}$ ) and water ad libitum. The project was approved by the Ethics Committee on Animal Research of the University of Sorocaba (n.010/2013), and it was conducted in accordance with the Brazilian Regulations for Animal Experimentation. The animals were housed in cages holding 3 rats each with free access to chow and water. They were exposed to a cycle of 12 hours of light and 12 hours of dark and kept at $22^{\circ} \mathrm{C}$.

Treatment: The animals were divided into 3 groups of 15 animals each: the TETRA Group, the TETRA+LG Group, and the CONTR Group. The treatments were given to each group once daily by an oral route using a gavage needle. TETRA was given a tetracycline dose of $75 \mathrm{mg}$ / $\mathrm{kg}$ /day; TETRA+LG was given a dose of tetracycline of $75 \mathrm{mg} / \mathrm{kg} /$ day followed 2 hours later by treatment with a $0.1-\mathrm{mL}$ suspension containing $10^{9} \mathrm{cfu}$ of $L$. gasseri (ATCC 33323). The CONTR group was given $0.1 \mathrm{~mL}$ of NaCL solution $(0.9 \%)$. The treatments were given for two weeks on days $0,2,4,7,9$, and 11 . The $L$. gasseri was dissolved in a saline solution containing $0.9 \% \mathrm{NaCL}$.

Probiotic: L. gasseri was obtained in a lyophilized form from the André Tosello Foundation (ATCC 33233 (American Type Culture Collection)) and maintained and grown in MRS BROTH (DE MAN, Rogosa, SHARPE).

\section{Weight gain and body composition}

Animal weight $(A W)$ : The rats were weighed weekly for 8 weeks on days $0,7,14,21,28,35,42,49$, and 56 . To assess body composition, the rats were measured and subjected to bioelectrical impedance analysis.

Body measurements: To measure the bodies of the animals, they were anesthetized with sodium pentobarbital $(30 \mathrm{mg} / \mathrm{kg}$ ) and measured as described previously. (Novelli et al., 2007) Abdominal circumference (AC) was measured immediately anterior to the forefoot, thoracic circumference (TC) was measured immediately behind the foreleg, and body length (BL) was the nose-anus length. We used a non-elastic strap with an accuracy of $0.1 \mathrm{~cm}$.

Bioelectrical impedance: Tetrapolar bioelectrical impedance analysis (TBIA) was performed according to a previously described procedure (Hall, Lukaski, Marchello, 1989) Whole-body reactance (WBXc) and whole-body resistance (WBR) were measured using a tetrapolar phase-sensitive bioelectrical impedance analyzer that introduced a $42-\mu \mathrm{A}$ current at $50 \mathrm{kHz}$ (Bioelectrical Body Composition Analyzer, Model: Quantum II). The anesthetized animals were placed in a prone position on a nonconductive surface. The hair was removed, and four electrodes (two sources and two detectors) made from hypodermic needles were placed as described previously (Hall, Lukaski, Marchello, 1989; Yokoi et al., 2001). Electrode 1 (a source) was placed at the anterior edge of the orbit, electrode 2 (a source) was placed $4 \mathrm{~cm}$ from the base of the tail, electrode 3 (a detector) was placed at the anterior opening of the pinna, and electrode 4 (a detector) was placed at the midpelvis.

We evaluated the following parameters for all animals using the data obtained from the TBIA (WBXc and WBR), the body measurements (AC, TC, and BL), and the animal weights (AW):

The body mass index (BMI) was calculated by divid- 
ing the weight of the animal in grams (AW) by the square of its length in centimeters (BL) (Novelli et al., 2007).

- $\quad$ The Lee index was determined by dividing the cubic root of the animal weight in grams (AW) by the length in centimeters (BL) (Bernardis, 1970).

- $\quad$ The AC/TC ratio was determined by dividing the $\mathrm{AC}$ in centimeters by the TC in centimeters.

- $\quad$ The total body water in grams (TBW) was estimated using a previously described empirical formula (Hall, Lukaski, Marchello, 1989), TBW = $15.47+$ 97.44 BL2/WBR, where BL is the body length in centimeters and WBR is in $\Omega$ and obtained from the TBIA.

- $\quad$ The percentage of body water $(\% \mathrm{BW})$ was calculated by dividing the TBW in grams by the animal weight in grams (AW) and multiplying the result by 100 .

\section{Statistical analysis}

All measurements were taken twice. The statistical significance between the three groups was calculated using a two-way analysis of variance (ANOVA), followed by the Tukey-Kramer test. A difference between groups was considered statistically significant when the $p$ value was $<0.05$.

\section{RESULTS}

Weight Gain: The rats were weighed weekly. Table I shows the initial weight average (day zero), the final weight medians (day 56), the average weight gain, and the standard deviation. We observed no difference in weight gain among the three groups.

The data in Figure 1 show that there was no variation in the weekly weight of the animals in any of the groups. The animals in all groups showed a fairly homogenous weight gain, with higher gain between the third and fourth weeks after the beginning of the experiment. Table II shows the results of the bioelectrical impedance for the WBXc and the WBR data. There was no difference between any groups tested in the bioelectrical impedance parameters evaluated.

Table III shows the results obtained from the body measurements and TBIA. The BMI was significantly higher in the TETRA group than in the CONTR group $(p=0.0302)$. The Lee index was significantly higher in the

TABLE I - Initial weight, final weight, and weight gain of animals [mean $( \pm \mathrm{SD})]$ for each group

\begin{tabular}{lcccc}
\hline & TETRA & TETRA+LG & CONTR & p \\
\hline Initial weight $(\mathrm{g})$ & $74.05( \pm 5.11) \mathrm{a}$ & $77.53( \pm 7.94) \mathrm{a}$ & $76.33( \pm 3.84) \mathrm{a}$ & 0.7161 \\
Final weight $(\mathrm{g})$ & $336.06( \pm 11.34) \mathrm{a}$ & $336.53( \pm 14.78) \mathrm{a}$ & $332.46( \pm 10.09) \mathrm{a}$ & 0.8835 \\
Weight gain $(\mathrm{g})$ & $261.13( \pm 7.38) \mathrm{a}$ & $259.00( \pm 11.66) \mathrm{a}$ & $256.13( \pm 7.63) \mathrm{a}$ & 0.7538 \\
\hline
\end{tabular}

TETRA - Tetracycline group (75 mg/kg/day); TETRA+LG - Tetracycline plus L.gasseri group (75 mg/Kg/day plus $10^{9}$ cfu); CONTR - Control group; Different superscripted letters, in same row, indicate statistical significance $p<0.05$.

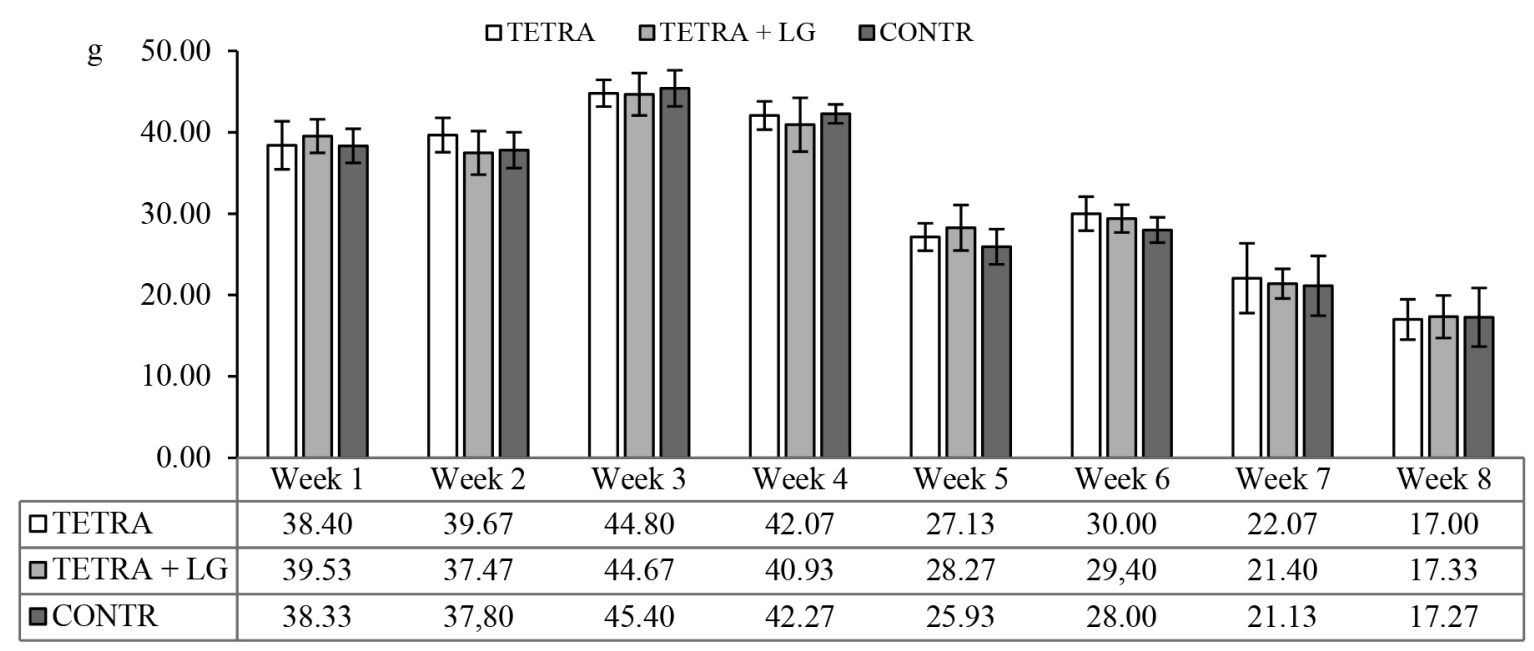

FIGURE 1 - Weekly average weight gain (g) and standard deviation. 
TABLE II - Bioelectrical impedance: whole body reactance (WBXc) and whole body resistance (WBR) for the three groups

\begin{tabular}{lcccc}
\hline & TETRA & TETRA+LG & CONTR & p \\
\hline WBXc & $26.67( \pm 2.35) \mathrm{a}$ & $23.00( \pm 2.38) \mathrm{a}$ & $24.40( \pm 2.30) \mathrm{a}$ & 0.1104 \\
WBR & $227.03( \pm 7.00) \mathrm{a}$ & $216.67( \pm 10.89) \mathrm{a}$ & $212.87( \pm 9.74) \mathrm{a}$ & 0.1067 \\
\hline
\end{tabular}

WBXc - Whole-body reactance; WBR - Whole-body resistance; TETRA - Tetracycline group $(75 \mathrm{mg} / \mathrm{kg} /$ day $)$; TETRA+LG Tetracycline plus L.gasseri group ( $75 \mathrm{mg} / \mathrm{kg} /$ day plus $\left.10^{9} \mathrm{cfu}\right)$; CONTR - Control group; Different superscripted letters, in same row, indicate statistical significance $p<0.05$.

TABLE III - BMI, Lee index, AC/TC ratio, TBW, and BW in all groups

\begin{tabular}{lcccc}
\hline & TETRA & TETRA+LG & CONTR & p \\
\hline BMI $(\mathrm{g} / \mathrm{cm} 2)$ & $0.615( \pm 0.029) \mathrm{a}$ & $0.576( \pm 0.031) \mathrm{a}, \mathrm{b}$ & $0.562( \pm 0.019) \mathrm{b}$ & 0.0302 \\
Lee index & $0.297( \pm 0.006) \mathrm{a}$ & $0.287( \pm 0.006) \mathrm{b}$ & $0.284( \pm 0.008) \mathrm{b}$ & 0.0082 \\
AC/TC ratio & $1.16( \pm 0.032) \mathrm{a}$ & $1.121( \pm 0.035) \mathrm{a}, \mathrm{b}$ & $1.110( \pm 0.025) \mathrm{b}$ & 0.0144 \\
TBW $(\mathrm{g})$ & $252.1( \pm 13.70) \mathrm{a}$ & $280.7( \pm 12.16) \mathrm{b}$ & $288.8( \pm 15.62) \mathrm{b}$ & 0.0024 \\
BW $(\%)$ & $76.42( \pm 4.25) \mathrm{a}$ & $84.50( \pm 4.41) \mathrm{b}$ & $87.29( \pm 5.47) \mathrm{b}$ & 0.0052 \\
\hline
\end{tabular}

BMI - Body Mass Index; AC/TC ratio - Abdominal Circumference / Thoracic Circumference Ratio; TBW (g) - Total body water in grams; BW (\%) - Percentage of body water; TETRA - Tetracycline group ( $75 \mathrm{mg} / \mathrm{kg} /$ day); TETRA $+\mathrm{LG}$ - Tetracycline plus L.gasseri group ( $75 \mathrm{mg} / \mathrm{kg} /$ day plus $\left.10^{9} \mathrm{cfu}\right)$; CONTR - Control group; Different superscripted letters, in same row, indicate statistical significance $p<0.05$.

TETRA group (which received only tetracycline) than the TETRA + LG and CONTR groups ( $p=0.0082)$, but there was no difference between the TETRA+LG and CONTR groups. The results for the $\mathrm{AC} / \mathrm{TC}$ ratio were similar to BMI, showing a difference between only the TETRA group and the CONTR group ( $p=0.0144)$.

The TBW and the BW results showed that the TETRA group, which received only the antibiotic, had a lower amount of body water $(252.1 \mathrm{~g})$ and the lowest percentage of body water $(76.42 \%)$, indicating a greater amount of fat $(p=0.0024$ and $p=0.0052)$. The administration of $L$. gasseri associated with tetracycline in the TETRA+LG group was able to protect against the accumulation of body fat that occurred in the TETRA animals with similar performance to the CONTR group.

\section{DISCUSSION}

Data from this study show that the animals treated with tetracycline alone had significantly lower body water percentage than the other groups, although the weight gain was equal for all groups. Other studies have shown similar results. Cho used a different methodology and showed that giving animals antibiotics increased their body fat, despite not finding differences in weight (Cho et al., 2012). There is ample evidence showing that the use of antibiotics may be causing weight gain in humans, especially when administered to children (Perrini, 1951;
Macdougall, 1957; Garly et al., 2006; Southern et al., 2012; Trasande et al., 2013).

This adverse effect should not limit the use of antibiotics. During the first years of life when respiratory infections most often occur, antibiotic use is more frequent and necessary (Razon et al., 2005; Del Fiol et al., 2013). However, the use of antibiotics in this age group is a great concern because the microbiotas are more susceptible to changes (dysbiosis) at this time (Li, Wang, Donovan 2014; Voreades, Kozil, Weir, 2014). Therefore, it is very important to understand that probiotics could provide protection against the adverse effects of antibiotics and protect the microflora of these children during antibacterial therapy. L. gasseri could be used as an alternative to protect against dysbiosis and the resulting weight gain.

Studies of L. gasseri in humans have shown decreases in abdominal adiposity, body weight, and waist and hip circumferences after oral use of probiotics (Kadooka et al., 2010; Jung et al., 2013). Several studies show that the use of this microorganism in rats decreased visceral fat by enhancing lipid excretion (Yonejima, Ushida, Mori, 2013), reduced adipocyte size (Sato et al., 2008; Hamad et al., 2009), and reduced body weight (Kang Yun, Park, 2010; Kang et al., 2013).

The role of the microbiota in obesity and interference by antibiotics are widely documented. This study has demonstrated that tetracycline increases the fat mass of treated animals, as in other studies, and that probiotics $(L$. 
gasseri in this case) could protect the microbiota while preventing or decreasing fat accumulation after the use of antibiotics. Other studies are necessary to elucidate the mechanism by which some probiotics interfere with weight loss or gain in order to combat malnutrition and obesity, which are two major problems afflicting global health.

\section{REFERENCES}

AGANS, R.; RIGSBEE, L.; KENCHE, H.; MICHAIL, S.; KHAMIS, H.J.; PALIY, O. Distal gut microbiota of adolescent children is different from that of adults. FEMS Microbiol. Ecol., v.77, n.2, p.404-412, 2011.

ANDERSON, A.D.; NELSON, J.M.; ROSSITER, S.; ANGULO, F.J. Public health consequences of use of antimicrobial agents in food animals in the United States. Microb. Drug Resist., v.9, n.4, p.373-379, 2003.

BACKHED, F.; LEY, R.E.; SONNENBURG, J.L.; PETERSON, D.A.; GORDON, J.I. Host-bacterial mutualism in the human intestine. Science, v.307, n.5717, p.1915-1920, 2005.

BERNARDIS, L.L. Prediction of carcass fat, water and lean body mass from Lee's "nutritive ratio" in rats with hypothalamic obesity. Experientia, v.26, n.7, p.789-90, 1970.

BIBILONI, M.D.; PONS, A.; TUR, J.A. Prevalence of overweight and obesity in adolescents: a systematic review. ISRN Obes., v.2013, p.392747, 2013.

MOREIRA, A.P.B.; TEIXEIRA, T.F.S.; PELUZIO, M.C.G.; ALFENAS, R.C.G. Gut microbiota and the development of obesity. Nutr. Hosp., v.27, n.5, p.1408-1414, 2012.

CHO, I.; YAMANISHI, S.; COX, L.; METHÉ, B.A.; ZAVADIL, J.; LI, K.; GAO, Z.; MAHANA, D.; RAJU, K.; TEITLER, I.; LI, H.; ALEKSEYENKO, A.V.; BLASER, M.J.et al. Antibiotics in early life alter the murine colonic microbiome and adiposity. Nature, v. 488, n. 7413, p. 621-626, 2012.

CHRISTIAN, T.; RASHAD, I. Trends in U.S. food prices, 19502007. Econ. Hum. Biol., v.7, n.1, p.113-120, 2009.

COLLADO, M.C.; ISOLAURI E.; LAITINEN K.; SALMINEN S. Distinct composition of gut microbiota during pregnancy in overweight and normal-weight women. Am. J. Clin. Nutr., v.88, n.4, p.894-899, 2008.
DEL FIOL, F.S.; LOPES, L.C.; BARBERATO-FILHO, S.; MOTTA, C.C. Evaluation of the prescription and use of antibiotics in Brazilian children. Braz. J. Infect. Dis., v.17, n.3, p.332-337, 2013.

GARLY, M.L.; BALÉ, C.; MARTINS, C.L.; WHITTLE, H.C.; NIELSEN, J.; LISSE, I.M.; AABY, P. Prophylactic antibiotics to prevent pneumonia and other complications after measles: community based randomised double blind placebo controlled trial in Guinea-Bissau. BMJ, v.333, n. 7581, p.1245, 2006.

GRZESKOWIAK, L.; COLLADO, MC.; MANGANI, C.; MALETA, K.; LAITINEN, K.; ASHORN, P.; ISOLAURI, E.; SALMINEN, S. Distinct gut microbiota in southeastern African and northern European infants. J. Pediatr. Gastroenterol. Nutr., v.54, n.6, p.812-816, 2012.

HAIGHT, T.H.; PIERCE, W.E. Effect of prolonged antibiotic administration of the weight of healthy young males. $J$. Nutr., v.56, n.1, p.151-161, 1955.

HALL, C.B.; LUKASKI, H.C.; MARCHELLO, M.J. Estimation of rat body composition using tetrapolar bioelectrical impedance analysis. Nutr. Rep. Int., v.39, n.3, p.627-633, 1989.

HAMAD, E.M.; SATO, M.; UZU, K.; YOSHIDA, T.; HIGASHI, S.; KAWAKAMI, H.; KADOOKA, Y.; MATSUYAMA, H.; ABD EL-GAWAD, I.A.; IMAIZUMI, K. Milk fermented by Lactobacillus gasseri SBT2055 influences adipocyte size via inhibition of dietary fat absorption in Zucker rats. Br. $J$. Nutr., v.101, n.5, p.716-724, 2009.

JUNG, S.P.; LEE, K.M.; KANG, J.H.; YUN, S.I.; PARK, H.O.; MOON, Y.; KIM, J.Y. Effect of Lactobacillus gasseri BNR17 on overweight and obese adults: a randomized, double-blind clinical trial. Korean J. Fam. Med., v.34, n.2, p.80-89, 2013.

KADOOKA, Y.; SATO, M.; IMAIZUMI, K.; OGAWA, A.; IKUYAMA, K.; AKAI, Y.; OKANO, M.; KAGOSHIMA, M.; TSUCHIDA, T. Regulation of abdominal adiposity by probiotics (Lactobacillus gasseri SBT2055) in adults with obese tendencies in a randomized controlled trial. Eur. $J$. Clin. Nutr., v.64, n.6, p.636-643, 2010.

KANG, J.H.; YUN, S.I.; PARK, H.O. Effects of Lactobacillus gasseri BNR17 on body weight and adipose tissue mass in diet-induced overweight rats. J. Microbiol., v.48, n.5, p.712-714, 2010. 
KANG, J.H.; YUN, S.I.; PARK, M.H.; PARK, J.H.; JEONG, S.Y.; PARK, H.O. Anti-obesity effect of Lactobacillus gasseri BNR17 in high-sucrose diet-induced obese mice. PLoS One, v.8, n.1, art.e54617, p.1-8, 2013.

LANKELMA, J.M.; NIEUWDORP, M.; DE VOS, W.M.; WIERSINGA, W.J. [The gut microbiota in sickness and health]. Ned. Tijdschr. Geneeskd., v.157, p.A5901, 2014.

LEY, R.E.; TURNBAUGH, P.J.; KLEIN, S.; GORDON, J.I. Microbial ecology: human gut microbes associated with obesity. Nature, v.444, n.7122, p.1022-1023, 2006.

LI, M.; WANG, B.; ZHANG, M.; RANTALAINEN, M.; WANG, S.; ZHOU, H.; ZHANG, Y.; SHEN, J.; PANG, X.; ZHANG, M.; WEI, H.; CHEN, Y.; LU, H.; ZUO, J.; SU, M.; QIU, Y.; JIA, W.; XIAO, C.; SMITH, L.M.; YANG, S.; HOLMES, E.; TANG, H.; ZHAO, G.; NICHOLSON, J.K.; LI, L.; ZHAO, L. Symbiotic gut microbes modulate human metabolic phenotypes. Proc. Natl. Acad. Sci. U. S. A., v.105, n.6, p.2117-2122, 2008 .

LI, M.; WANG, M.; DONOVAN, S.M. Early development of the gut microbiome and immune-mediated childhood disorders. Semin. Reprod. Med., v.32, n.1, p.74-86, 2014.

MACDOUGALL, L. G. The effect of aureomycin on undernourished African children. J. Trop. Pediatr., v.3, n.2, p.74-81, 1957.

MARKLE, J.G.; FRANK, D.N.; MORTIN-TOTH, S.; ROBERTSON, C.E.; FEAZEL, L.M.; ROLLEKAMPCZYK, U.; VON BERGEN, M.; MCCOY, K.D.; MACPHERSON, A.J.; DANSKA, J.S. Sex differences in the gut microbiome drive hormone-dependent regulation of autoimmunity. Science, v.339, n.6123, p.1084-1088, 2013.

MARTINEZ, F.D. The human microbiome: early life determinant of health outcomes. Ann Am Thorac Soc., v.11, suppl.1, p.S7-S12, 2014.

MILLION, M.; ANGELAKIS, E.; PAUL, M.; ARMOUGOM, F.; LEIBOVICI, L.; RAOULT, D. Comparative metaanalysis of the effect of Lactobacillus species on weight gain in humans and animals. Microb. Pathog., v.53, n.2, p.100-108, 2012.

MILLION, M.; LAGIER, J.C.; YAHAV, D.; PAUL, M. Gut bacterial microbiota and obesity. Clin. Microbiol. Infect., v.19, n.4, p.305-313, 2013.
MUSSO, G.; GAMBINO, R.; CASSADER, M. Interactions between gut microbiota and host metabolism predisposing to obesity and diabetes. Annu. Rev. Med., v.62, p.361-380, 2011 .

NEWNHAM, J.P.; PENNELL, C.E.; LYE, S.J.; RAMPONO, J.; CHALLIS, J.R. Early life origins of obesity. Obstet. Gynecol. Clin. North Am., v.36, n.2, p.227-244, 2009.

NOVELLI, E.L.; DINIZ, Y.S.; GALHARDI, C.M.; EBAID, G.M.; RODRIGUES, H.G.; MANI, F.; FERNANDES, A.A.; CICOGNA, A.C.; NOVELLI FILHO, J.L. Anthropometrical parameters and markers of obesity in rats. Lab. Anim., v.41, n.1, p.111-119, 2007.

PERRINI, F. [Aureomycin as growth factor in prematures]. Boll. Soc. Ital. Biol. Sper., v.27, n.7/8, p.1151-1152, 1951.

PUTIGNANI, L.; DEL CHIERICO, F.; PETRUCCA, A.; VERNOCCHI, P.; DALLAPICCOLA, B. The human gut microbiota: a dynamic interplay with the host from birth to senescence settled during childhood. Pediatr. Res., v.76, n.1, p.2-10, 2014.

QUIGLEY, E.M. Gut bacteria in health and disease. Gastroenterol. Hepatol., v.9, n.9, p.560-569, 2013.

RAZON, Y.; ASHKENAZI, S.; COHEN, A.; HERING, E.; AMZEL, S.; BABILSKY, H.; BAHIR, A.; GAZALA, E.; LEVY, I. Effect of educational intervention on antibiotic prescription practices for upper respiratory infections in children: a multicentre study. J. Antimicrob. Chemother, v.56, n.5, p.937-940, 2005.

RILEY, L.W.; RAPHAEL, E.; FAERSTEIN, E. Obesity in the United States - dysbiosis from exposure to low-dose antibiotics? Front. Public Health, v.1, p.69, 2013.

SAIMAN, L.; ANSTEAD, M.; MAYER-HAMBLETT, N.; LANDS, LC.; KLOSTER, M.; HOCEVAR-TRNKA, J.; GOSS, CH.; ROSE, LM.; BURNS, JL.; MARSHALL, BC.; RATJEN, F.; AZ0004 AZITHROMYCIN STUDY GROUP. Effect of azithromycin on pulmonary function in patients with cystic fibrosis uninfected with Pseudomonas aeruginosa: a randomized controlled trial. JAMA, v.303, n.17, p.1707-1715, 2010. 
SAIMAN, L.; MAYER-HAMBLETT, N.; ANSTEAD, M.; LANDS, LC.; KLOSTER, M.; GOSS, CH.; ROSE, LM.; BURNS, JL.; MARSHALL, BC.; RATJEN, F.; AZ0004 MACROLIDE STUDY TEAM. Open-label, follow-on study of azithromycin in pediatric patients with CF uninfected with Pseudomonas aeruginosa. Pediatr. Pulmonol., v.47, n.7, p.641-648, 2012.

SARMAH, A.K.; MEYER, M.T.; BOXALL, A.B. A global perspective on the use, sales, exposure pathways, occurrence, fate and effects of veterinary antibiotics (VAs) in the environment. Chemosphere, v.65, n.5, p.725-759, 2006.

SATO, M.; UZU, K.; YOSHIDA, T.; HAMAD, E.M.; KAWAKAMI, H.; MATSUYAMA, H.; ABD EL-GAWAD, I.A.; IMAIZUMI, K. Effects of milk fermented by Lactobacillus gasseri SBT2055 on adipocyte size in rats. Br. J. Nutr., v.99, n.5, p.1013-1017, 2008.

SCHWIERTZ, A.; TARAS, D.; SCHÄFER, K.; BEIJER, S.; BOS, N.A.; DONUS, C.; HARDT, P.D. Microbiota and SCFA in lean and overweight healthy subjects. Obesity, v.18, n.1, p.190-195, 2010.

SOUTHERN, K.W.; BARKER, P.M.; SOLIS-MOYA, A.; PATEL, L. Macrolide antibiotics for cystic fibrosis. Cochrane Database Syst. Rev., v.11, p.CD002203, 2012.

THUNY, F. RICHET, H.; CASALTA, J.P.; ANGELAKIS, E.; HABIB, G.; RAOULT, D. Vancomycin treatment of infective endocarditis is linked with recently acquired obesity. PLoS One, v.5, n.2, art.e9074, p.1-6, 2010.

TILG, H.; KASER, A. Gut microbiome, obesity, and metabolic dysfunction. J. Clin. Invest., v.121, n.6, p.2126-2132, 2011.

TRASANDE, L.; BLUSTEIN, J.; LIU, M.; CORWIN, E.; COX, L.M.; BLASER, M.J. Infant antibiotic exposures and earlylife body mass. Int. J. Obes., v.37, n.1, p.16-23, 2013.

TURNBAUGH, P.J.; BÄCKHED, F.; FULTON, L.; GORDON, J.I. Diet-induced obesity is linked to marked but reversible alterations in the mouse distal gut microbiome. Cell. Host. Microbe, v.3, n.4, p.213-223, 2008.
TURNBAUGH, P.J.; HAMADY, M.; YATSUNENKO, T.; CANTAREL, B.L.; DUNCAN, A.; LEY, R.E.; SOGIN, M.L.; JONES, W.J.; ROE, B.A.; AFFOURTIT, J.P.; EGHOLM, M.; HENRISSAT, B.; HEATH, A.C.; KNIGHT, R.; GORDON, J.I. A core gut microbiome in obese and lean twins. Nature, v.457, n.7228, p.480-484, 2009.

VAEL, C.; VERHULST, S.L.; NELEN, V.; GOOSSENS, H.; DESAGER, K.N. Intestinal microflora and body mass index during the first three years of life: an observational study. Gut Pathog., v.3, n.1, p.8, 2011.

VAN BOECKEL, T.P.; GANDRA, S.; ASHOK, A.; CAUDRON, Q.; GRENFELL, B.T.; LEVIN, S.A.; LAXMINARAYAN, R. Global antibiotic consumption 2000 to 2010: an analysis of national pharmaceutical sales data. Lancet Infect. Dis., v.14, n.8, p.742-750, 2014.

VOREADES, N.; KOZIL, A.; WEIR, T.L. Diet and the development of the human intestinal microbiome. Front. Microbiol., v.5, p.494, 2014.

XU, P.; LI, M.; ZHANG, J.;ZHANG, T. Correlation of intestinal microbiota with overweight and obesity in Kazakh school children. BMC Microbiol., v.12, p.283, 2012.

YOKOI, K.; LUKASKI, H.C.; UTHUS, E.O.; NIELSEN, F.H. Use of bioimpedance spectroscopy to estimate body water distribution in rats fed high dietary sulfur amino acids. $J$. Nutr., v. 131, n. 4, p. 1302-1308, 2001.

YONEJIMA, Y.; USHIDA, K.; MORI, Y. Lactobacillus gasseri NT decreased visceral fat through enhancement of lipid excretion in feces of KK-A(y) mice. Biosci. Biotechnol. Biochem., v.77, n.11, p.2312-2325, 2013.

Received for publication on $06^{\text {th }}$ April 2016 Accepted for publication on $09^{\text {th }}$ November 2016 